\title{
Nutrient stimulation of lytic phage production in bacterial populations of the Gulf of Mexico
}

\author{
S. J. Williamson, J. H. Paul* \\ University of South Florida, College of Marine Science, 140 7th Avenue South, St. Petersburg, Florida 33701, USA
}

\begin{abstract}
The effect of nutrient addition on prophage induction in marine water samples was investigated during a 2001 research cruise in the Gulf of Mexico. To test the hypothesis that prophage induction could be stimulated by nutrient addition, water samples were treated with inorganic and organic nutrients in combination with mitomycin $\mathrm{C}\left(1.0 \mu \mathrm{g} \mathrm{ml}^{-1}\right)$ or with the nutrient alone as controls. An increase in phage abundance was observed at 3 stations in response to additions of $\mathrm{PO}_{4}{ }^{3-}$ (mesotrophic Mississippi River plume, oligotrophic surface-water, and Dry Tortugas stations), $\mathrm{NH}_{4}{ }^{+}$ (oligotrophic surface-water station), and several organic compounds (oligotrophic surface-water station). Augmented phage production occurred in both the presence and absence of mitomycin $\mathrm{C}$, indicating that inorganic and organic nutrient addition did not appear to stimulate prophage induction. These results suggest that nutrient amendment of environmental samples caused a stimulation of lytic phage production that may have resulted from a stimulation of host-cell growth. However, these results do not preclude nutrient stimulation of prophage induction at other times of the year or in other oceanic environments, which were not examined in this study.
\end{abstract}

KEY WORDS: Lysogeny · Prophage induction · Lytic phage production

\section{INTRODUCTION}

Viruses that infect bacteria (bacteriophages) are now known to be the most abundant organisms in the marine environment, often exceeding bacteria by 1 to 2 orders of magnitude. Viral abundances can range from $<10^{4}$ to $>10^{8} \mathrm{ml}^{-1}$, with the highest abundances occurring in eutrophic areas of the marine environment (i.e. coastal regions) and the lowest abundances in oligotrophic areas (i.e. open ocean) (Wommack \& Colwell 2000).

Phage lysis of bacteria has important global implications for the cycling of carbon through microbial-based food webs in the marine environment. Viral-mediated cell lysis liberates dissolved organic carbon (DOC) into the surrounding environment, essentially preventing its flow to higher trophic levels (micro and macrozooplankton) by providing a source of utilizable carbon to bacterial populations, thereby stimulating bacterial production (Fuhrman 1992). Therefore, an increase in lytic bacteriophage production in the marine environ- ment would result in greater bacterial respiration and production of $\mathrm{CO}_{2}$. Viral lysis of host cells also influences the cycling of other essential nutrients in the marine environment, namely nitrogen (N) and phosphorus (P). Cellular components such as nucleic and amino acids are rich in organic $\mathrm{P}$ and $\mathrm{N}$ respectively, which become available for assimilation by heterotrophic bacteria upon liberation by viral lysis of host cells (Wilhelm \& Suttle 1999).

Viral infection of host cells can result in different types of interactions. Lytic infection, by far the best studied of the virus-host interactions, results in immediate host-cell death via lysis following the replication of viral particles. In lysogeny, the phage genome establishes a silent infection within one of the host's cellular replicons (chromosome, plasmid or another phage genome) (Ackermann \& Dubow 1987). This process proves beneficial to both the host cell and phage. The host cell provides a safe repository for the viral genome in times of low host-cell abundance (Stewart \& Levin 1984), and in turn benefits from the process of 
conversion, or the expression of phage genes. This can include toxin production, antibiotic resistance, expanded metabolic capabilities, and homoimmunity (resistance to superinfection by the same or closely related phages) (Levin \& Lenski 1983).

The environmental factors that determine lytic versus lysogenic infections by temperate phage are poorly understood. Several studies have suggested that availability of nutrients may have an important influence upon whether viruses enter into lytic or lysogenic interactions with their host cells (Bratbak et al. 1993, Tuomi et al. 1995, Wilson et al. 1996, Wilson \& Mann 1997, Hewson et al. 2001). Wilson \& Mann (1997) proposed that lysogenic interactions are favored when nutrient concentrations are low and the virus to host cell ratio high. Inorganic nutrient limitation, particularly $\mathrm{PO}_{4}{ }^{-3}$, has been suggested as a possible constraint on viral replication and/or prophage induction (Wilson \& Mann 1997). Wilson et al. (1996) found that $100 \%$ of Synechocococcus sp. WH7803 cells underwent viral lysis under phosphate-replete conditions, while only $9.3 \%$ of the cells were lysed by viruses under phosphate-limited conditions. Similarly, Tuomi et al. (1995) observed a significant decrease in bacterial abundance upon the addition of inorganic phosphate to phosphate-deplete seawater samples from Raunefjorden, Norway. Bratbak et al. (1993) also provided evidence that phosphate limitation resulted in the inhibition of viral replication in the marine coccolithophorid Emiliania huxleyi, and suggested that these results may have been caused by the viruses' high nucleic acid to protein ratio.

The effect that other inorganic nutrients have on virus-host interactions has been less well studied. Hewson et al. (2001) observed a stimulation of viral production in eutrophic waters of the Brisbane River by 14 to $52 \%$ above ambient levels upon addition of the inorganic nutrients $\mathrm{NO}_{3}{ }^{-}, \mathrm{NH}_{4}{ }^{+}, \mathrm{PO}_{4}{ }^{3-}$ and $\mathrm{SiO}_{3}$, suggesting that inorganic nutrient concentrations may influence viral abundance in aquatic environments.

In this study, we investigated the effect of nutrient addition on prophage induction by bacterial populations in marine water samples obtained from mesotrophic and oligotrophic areas of the Gulf of Mexico during a 2001 research cruise aboard the RV 'F. G. Walton Smith'.

\section{MATERIALS AND METHODS}

Sampling sites. Surface-water samples were collected from 4 stations in the Gulf of Mexico during a July 2001 research cruise aboard the RV 'F. G. Walton Smith'. Stns 3 and 7 were both located within the mesotrophic Mississippi River plume, Stn 8 was an oligotrophic open water station, and Stn 10 was located in the Dry Tortugas (see Fig. 1).

Viral-reduction of sampled seawater. A modification of the viral-reduction method of Weinbauer \& Suttle (1996) was employed to reduce the ambient background levels of viruses in the water samples: Samples were not pre-filtered with a $1.0 \mu \mathrm{m}$ filter in order to reduce grazers as done by Weinbauer \& Suttle (1996). Using a $47 \mathrm{~mm}$ polycarbonate filtration apparatus to reduce the volume to approximately $5 \mathrm{ml}, 60 \mathrm{ml}$ of the sample water was filtered through a $0.22 \mu \mathrm{m}$ Poretics filter. Virus-free seawater was produced by filtration through a $0.02 \mu \mathrm{m}$ Whatman filter. To the remaining $5 \mathrm{ml}$ of the $0.22 \mu \mathrm{m}$-filtered sample, $50 \mathrm{ml}$ of $0.02 \mu \mathrm{m}$-filtered sample water was re-added, and the volume was once again reduced to approximately $5 \mathrm{ml}$ through filtration. The bacteria retained on the filter, along with the filter, were resuspended in $40 \mathrm{ml}$ $0.02 \mu \mathrm{m}$-filtered virus-free seawater in a sterile, acidwashed, polycarbonate, $125 \mathrm{ml}$ volume flask. The filter was removed and $0.02 \mu \mathrm{m}$-filtered virus-free sample water was added to bring the final volume to $60 \mathrm{ml}$. We then fixed $10 \mathrm{ml}$ of the viral-reduced sample with $0.02 \mu \mathrm{m}$-filtered formalin for viral and bacterial direct counts. The remainder of the viral-reduced sample was equally divided $(25 \mathrm{ml})$ and placed in sterile $50 \mathrm{ml}$ Sarstedt test tubes (Corning) for determination of lysogeny.

Enumeration of viruses and bacteria. Water samples were stained according to the Noble \& Fuhrman (1998) method except that SYBR gold nucleic acid stain was used (Chen at al. 2001), and staining time was reduced to $12 \mathrm{~min}$.

Induction of viral-reduced and unaltered samples with mitomycin C. Equal volumes $(25.0 \mathrm{ml})$ of viralreduced and unaltered samples were either treated with the mutagen mitomycin C $\left(1.0 \mu \mathrm{g} \mathrm{ml}{ }^{-1}\right.$, Sigma Chemical) or left untreated as controls. All samples were incubated statically at room temperature in the dark for $24 \mathrm{~h}$. Samples were fixed with $0.02 \mu \mathrm{m}$-filtered formalin ( $1 \%$ final concentration) following incubation. Triplicate slides were immediately prepared for direct counts as described above and stored frozen until counted.

Induction of viral-reduced and unaltered samples in presence of inorganic and organic nutrients. Unaltered (Stn 3) and viral-reduced (Stns 7, 8, and 10) water samples were treated with either inorganic or organic nutrients in order to determine their influence on prophage induction (Sigma Chemical). Treatment and control samples had the ambient viral population reduced as described previously. Unaltered samples $(25 \mathrm{ml})$ at Stn 3 were either treated with a combination of mitomycin $\mathrm{C}\left(1.0 \mu \mathrm{g} \mathrm{ml}^{-1}\right)$ and the inorganic nutrients phosphate $\left(\mathrm{KH}_{2} \mathrm{PO}_{4}, 10 \mu \mathrm{M}\right.$ final concentration), 
ammonium $\left(\mathrm{NH}_{4} \mathrm{Cl}\right)$, or nitrate $\left(\mathrm{NaNO}_{3}\right)$ (both $50 \mu \mathrm{M}$ final concentration), or were treated with the inorganic nutrients alone (control). Viral-reduced samples at Stn 7 were either treated with a combination of mitomycin $\mathrm{C}\left(1.0 \mu \mathrm{g} \mathrm{ml}^{-1}\right)$ and the organic nutrients L-glutamic acid, D-glucose (both $50 \mu \mathrm{M}$ concentration), d-ATP (2'deoxyadenosine 5' triphosphate), d-AMP (2' deoxyadenosine 5' monophosphate), or 2' deoxyadenosine (all $10 \mu \mathrm{M}$ final concentration), or were treated with the organic nutrients alone (control). Viral-reduced water samples at Stn 8 were treated with a combination of mitomycin $\mathrm{C}\left(1.0 \mu \mathrm{g} \mathrm{ml}^{-1}\right)$ and all the inorganic and organic nutrients listed for Stns 3 and 7 or were treated with the nutrients alone as controls. Viralreduced water samples at Stn 10 were treated with a combination of mitomycin $\mathrm{C}\left(1.0 \mu \mathrm{g} \mathrm{ml}^{-1}\right)$ and a gradient of $\mathrm{PO}_{4}{ }^{3-}$ concentrations $(0.1,1.0$ and $10.0 \mu \mathrm{M})$, or were treated with the gradient $\mathrm{PO}_{4}{ }^{3-}$ concentrations alone (control).

Nutrient analyses. $\mathrm{NH}_{3}, \mathrm{NO}_{3}{ }^{-}+\mathrm{NO}_{2}{ }^{-}$, and $\mathrm{PO}_{4}{ }^{3-}$ concentrations were determined for unfiltered and filtered water samples. For the filtered samples, a Swinex filtration device containing a $0.4 \mu \mathrm{m}$ Poretics filter was rinsed first with $10 \mathrm{ml} 10 \% \mathrm{HCl}$ in order to clean the filter, and then rinsed again with ultra-pure water (Millipore Milli-Q). All water samples were stored in $30 \mathrm{ml}$ polycarbonate bottles (Nalgene) at $-20^{\circ} \mathrm{C}$ until processing. $\mathrm{NO}_{3}{ }^{-}$and $\mathrm{PO}_{4}{ }^{3-}$ concentrations were measured with a Technicon AutoAnalyzer. $\mathrm{NH}_{4}{ }^{+}$concentrations were measured manually with the phenol/ hypochlorite technique (Grasshoff et al. 1999).

Statistical analysis of data. The number of viruses and bacteria enumerated following independent treatments were compared using a 1-way analysis of variance (ANOVA) in conjunction with Tukey's pairwise comparison in order to determine statistical differences between treatments, using Minitab statistical software.

\section{RESULTS}

Fig. 1 comprises a 7 d composite 'sea-viewing wide field-of-view sensor' (SeaWiFS) satellite image depicting chlorophyll a concentrations in the eastern Gulf of Mexico. The delivery of nutrients to the Gulf of Mexico via the Mississippi River causes the formation of a lowsalinity, high-productivity plume approximately $10 \mathrm{~m}$

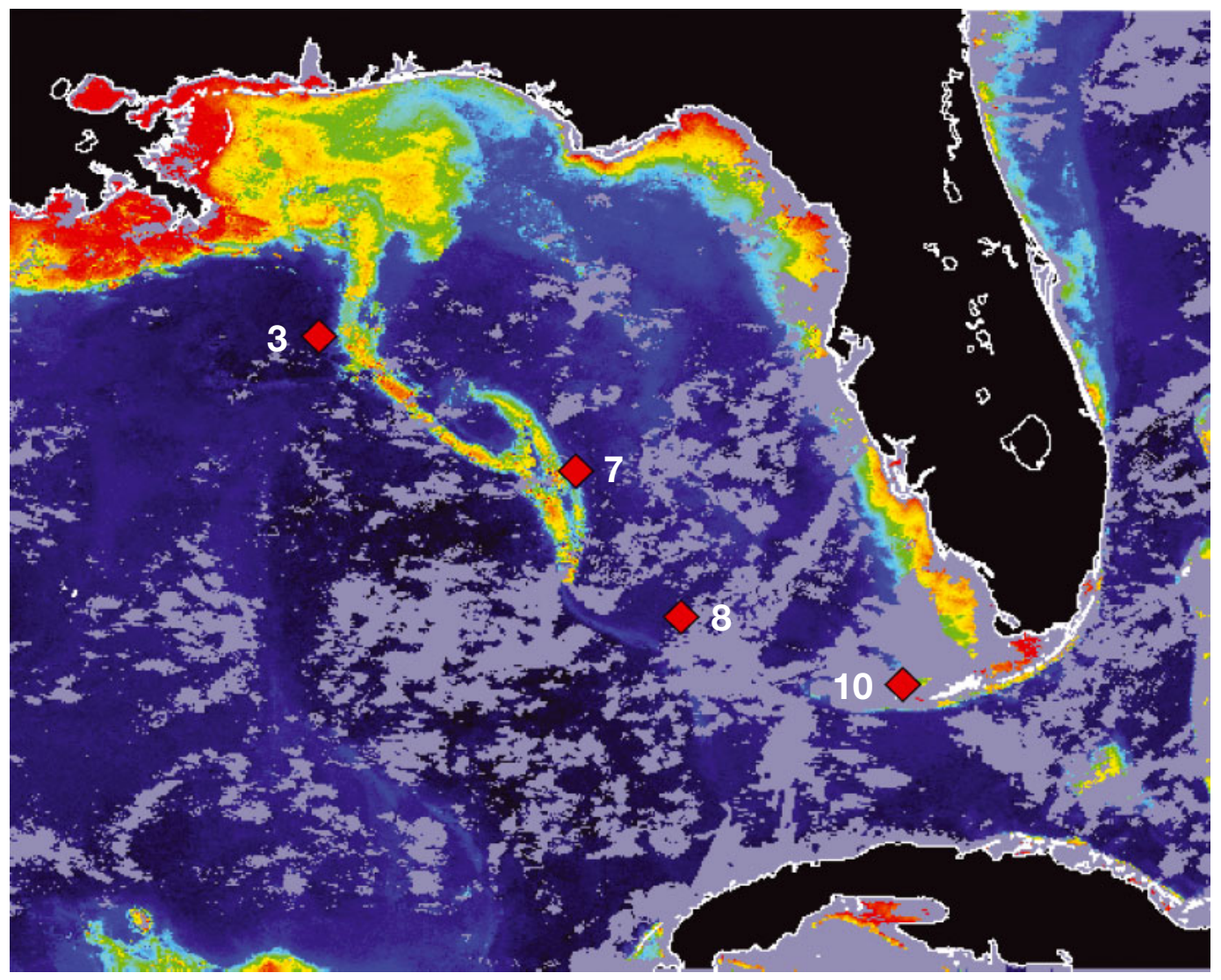

Fig. 1. Sea-viewing field-of-view sensor (SeaWiFS) image depicting chlorophyll a (chl a) concentration patterns in eastern Gulf of Mexico in July 2001, based upon 7 d composite images. Yellow and red indicate increased concentrations and blue low concentrations of chl $a_{\text {; }}$ black: land and clouds; red diamonds: station locations 
thick. At the time of sampling, the Mississippi River plume covered an approximate area of $33475 \mathrm{~km}^{2}$, accounting for roughly $9.16 \%$ of the oligotrophic NE Gulf of Mexico (B. Wawrik et al. unpubl. data). Surface-water samples that were treated with nutrients and screened for prophage induction comprised those from Stns 3, 7, 8 and 10. Stn 3 was characterized as a mixture of both mesotrophic plume and oligotrophic open water, since it was located within an eddy that had appeared to have developed from the body of the plume. Stn 7 was located along the distal portion of the plume, and Stn 8 was located in oligotrophic, non-plume waters. Stn 10, the most coastal station, was located in the Dry Tortugas.

Additional station characteristics comprising water temperature, salinity, nutrient data, and N:P ratios are presented in Table 1. Measurements were taken at Stns 3, 7 and 8 only. Water temperature was similar at all stations, averaging $29.2^{\circ} \mathrm{C}$. Salinity measurements ranged from 33.5 to 36.1 . The oligotrophic offshore waters of Stn 8 were the most saline (36.1), while the lowest salinity was measured at Plume Stn 7 (33.5). Stn 3 had a salinity intermediate between that of 7 and 8 (34.2) due to the influence of both low-salinity plume water and higher-salinity offshore water.

Dissolved inorganic nutrient levels $\left(\mathrm{NH}_{3}, \mathrm{NO}_{2}+\mathrm{NO}_{3}\right.$, and $\mathrm{PO}_{4}{ }^{3-}$ ) were also measured at Stns 3, 7 and 8 , and the N:P ratios calculated. Total inorganic N concentra-

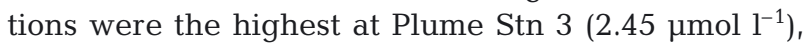
the lowest at Open-water Stn $8\left(0.213 \mu \mathrm{mol} \mathrm{l}^{-1}\right)$, and intermediate at Plume Stn $7\left(0.614 \mu \mathrm{mol} \mathrm{l}^{-1}\right)$. Since P concentrations were similar for all 3 stations (average $0.290 \mu \mathrm{mol} \mathrm{\textrm {l } ^ { - 1 }}$ ), total inorganic nitrogen concentration heavily influenced the N:P ratios.

Fig. 2 depicts the effect of inorganic nutrients on virus-like particles (Fig. 2A) and bacterial abundance (Fig. 2B) at Stn 3. Incubation of water samples with $\mathrm{PO}_{4}{ }^{3-}$ over a $24 \mathrm{~h}$ period produced a statistically significant increase in viruses $(\mathrm{p}<0.001)$ compared to all other treatments, including $\mathrm{PO}_{4}{ }^{-3}$ and mitomycin $\mathrm{C}$, mitomycin $\mathrm{C}$ alone, or nitrogen amendments. The increase in viruses observed in the $\mathrm{PO}_{4}{ }^{3-}$ treated samples appeared to be in response to an increase in bacterial abundance (Fig. 2B) in the same samples. For example, the bacterial population did not increase in the unaltered control $\left(t_{0}=6.60 \times 10^{5} \mathrm{ml}^{-1} ; t_{24}=6.86 \times\right.$ $10^{5} \mathrm{ml}^{-1}$ ), but increased to $2.14 \times 10^{6} \mathrm{ml}^{-1}$ in the sample treated with $\mathrm{PO}_{4}{ }^{3-}$ alone, a $224 \%$ change. Statistically significant increases in bacteria were observed in the sample treated with $\mathrm{PO}_{4}{ }^{3-}$ and mitomycin $\mathrm{C}(\mathrm{p}=0.032)$ as well as the sample treated with $\mathrm{PO}_{4}{ }^{3-}$ alone $(\mathrm{p}=$ $0.004)$.
The effects of inorganic and organic nutrient addition on virus-like particles and bacterial abundance at Stn 8 are shown in Figs. 3 \& 4 respectively. Stn 8 water contained less inorganic nutrients, especially with respect to total inorganic nitrogen concentration. At this station, the addition of both $\mathrm{PO}_{4}{ }^{3-}$ and $\mathrm{NH}_{4}{ }^{+}$to water samples resulted in statistically significant increases in viral direct counts compared to controls that did not receive inorganic nutrient amendment (with or without mito-
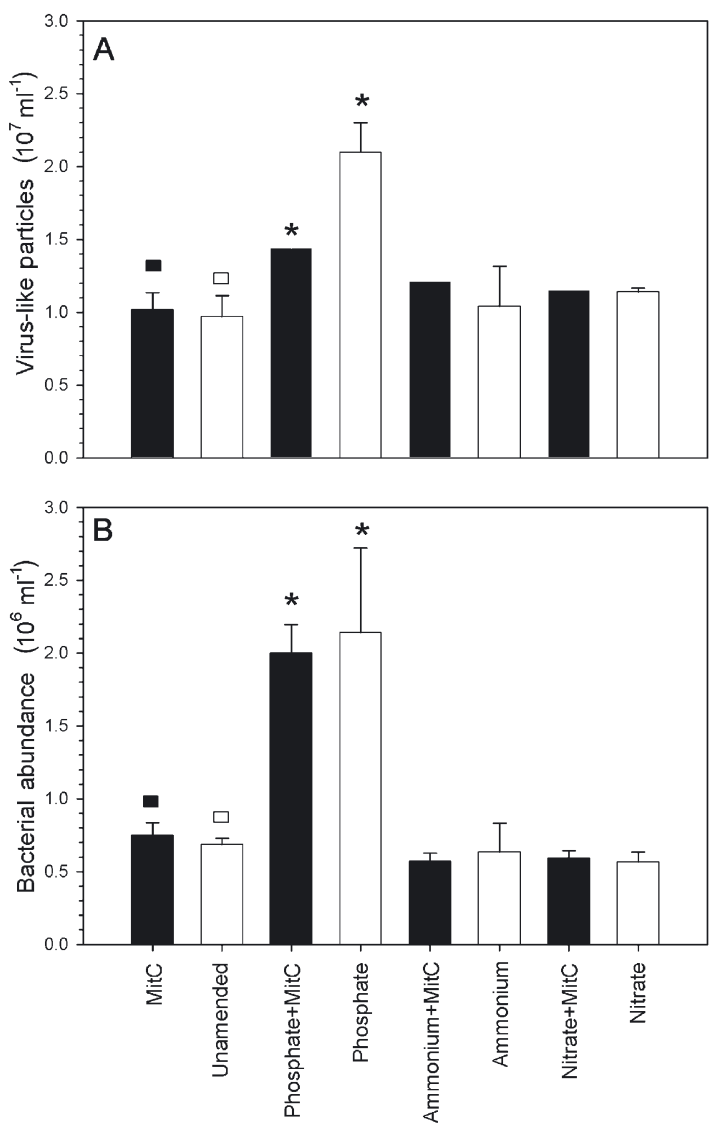

Fig. 2. (A) Viral and (B) bacterial abundance at Stn 3 following $24 \mathrm{~h}$ incubation with inorganic nutrients. Viral and bacterial abundances at $t=0$ were $1.32 \times 10^{7} \pm 5.88 \times 10^{6} \mathrm{ml}^{-1}$ and $6.60 \times 10^{5} \pm 1.17 \times 10^{5} \mathrm{ml}^{-1}$ respectively. *: statistically significant increase in viruses or bacteria $(95 \% \mathrm{CI})$ compared to non-nutrient amended control; ( $\square$ ) mitomycin C-treated (Mit C) controls; $(\square)$ untreated controls. Error bars $=\mathrm{SD}$; $\mathrm{n}=3$ slides 

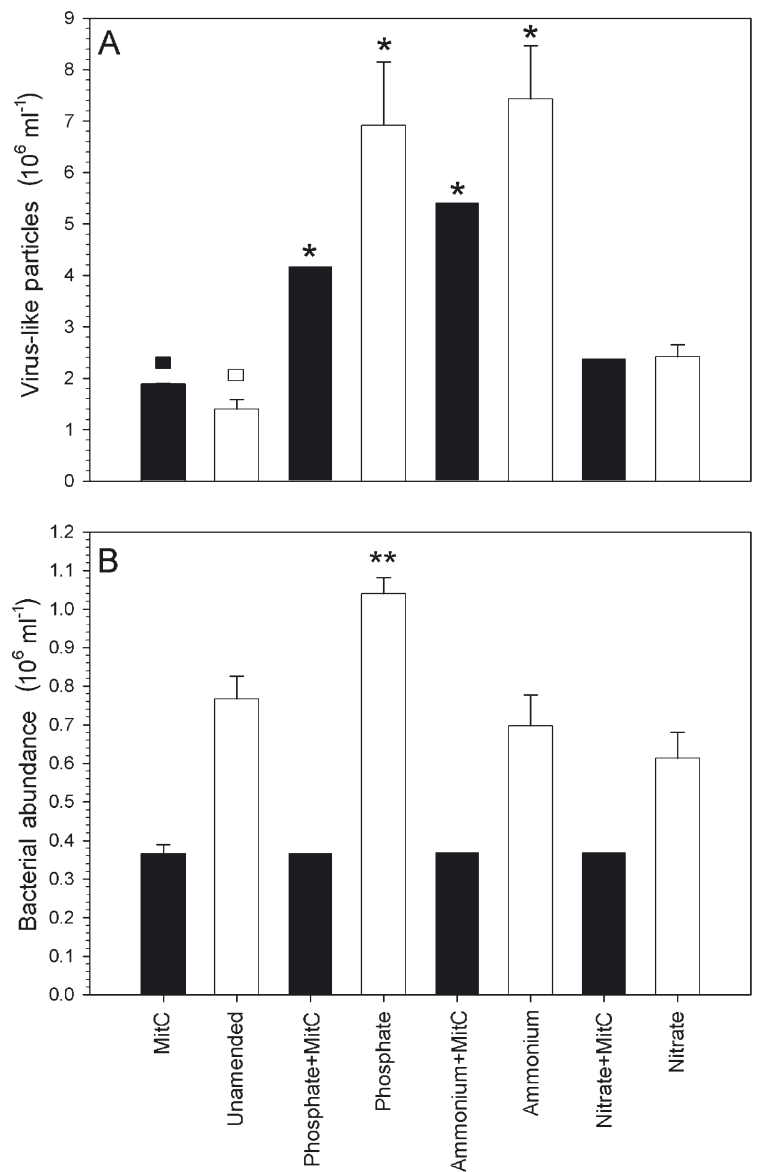

Fig. 3. (A) Viral and (B) bacterial abundance at Stn 8 following $24 \mathrm{~h}$ incubation with inorganic nutrients. Viral and bacterial abundances at $t=0$ were $1.23 \times 10^{6} \pm 1.30 \times 10^{5} \mathrm{ml}^{-1}$ and $4.44 \times 10^{5} \pm 1.51 \times 10^{5} \mathrm{ml}^{-1}$ respectively. * **: statistically significant increase in viruses and bacteria respectively $(95 \%$ CI) compared to non-nutrient amended control. Shading and error bars as for Fig. 2

mycin C) $(p<0.001)$ (Fig. 3A). Similar to Stn 3, the addition of these nutrients to their respective mitomycin C-treated samples did not cause a significant increase in viruses over the samples treated with the nutrient alone, suggesting that lytic production of phage was responsible for the increased viral abundance. The addition of $\mathrm{PO}_{4}{ }^{3-}$ to the water sample resulted in an increase in bacterial abundance (Fig. 3B) compared to the sample that did not receive phosphate treatment, yet the addition of $\mathrm{NH}_{4}{ }^{+}$to the sample did not produce a similar result. For the samples treated with mitomycin C, addition of $\mathrm{PO}_{4}{ }^{3-}, \mathrm{NH}_{4}{ }^{+}$, and $\mathrm{NO}_{3}{ }^{-}$did not cause an increase in bacterial abundance compared to the samples that only received mitomycin C.

The effect of organic nutrient addition on prophage induction was investigated at Stns 7 and 8. Results are not shown for Stn 7 since addition of organic nutrients to water samples did not result in any detectable increases in viruses at this station. Conversely, the
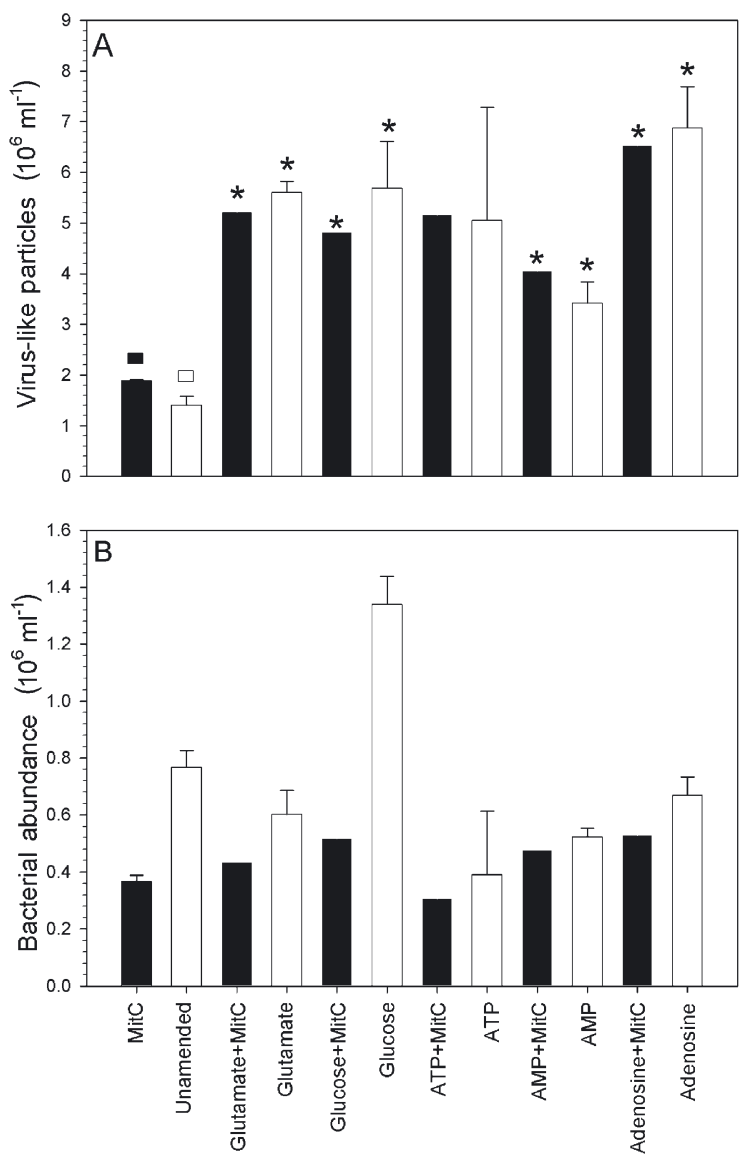

Fig. 4. (A) Viral and (B) bacterial abundance at Stn 8 following $24 \mathrm{~h}$ incubation with organic nutrients. *: statistically significant increase in viruses (95\% CI) compared to non-nutrient amended control; no statistically significant difference was observed in bacterial abundance between mitomycin C-treated and untreated samples. Shading and error bars as for Fig. 2

addition of glutamate, glucose, AMP and adenosine (in combination with or without mitomycin C) to water samples at Stn 8 resulted in all cases in statistically significant increases in virus-like particles over controls that did not receive the same organic nutrient treatment ( $p$ 0.001) (Fig. 4A). ATP amendment appeared to result in a similar increase in virus-like particles, but the increase was not significant. Similar to the inorganic nutrient results, the addition of mitomycin $\mathrm{C}$ to the samples (in combination with the nutrient) did not cause an increase in viral abundance compared to the respective nutrient-amended control (no mitomycin C). In fact, in both situations, viral direct counts were lower in samples that were treated with mitomycin C (in conjunction with a nutrient) than when the nutrient was added alone. Again, this suggests that lytic production of phage was occurring at this station, with no evidence of a nutrient stimulation of prophage induction. 
While nutrient stimulation of bacterial growth (reflected by an increase in bacterial abundance) appeared to be more effective when the organic nutrients were added to samples alone (Fig. 4B), the addition of mitomycin $\mathrm{C}$ to the samples seemed to inhibit bacterial growth. Although bacterial direct counts appeared higher in samples that received the organic nutrient alone, only the sample that was treated with glucose produced significantly higher bacterial numbers than the sample that received no nutrient addition.

Fig. 5 shows the results of varying $\mathrm{PO}_{4}{ }^{3-}$ concentrations on viral (Fig. 5A) and bacterial (Fig. 5B) abundance in coastal waters of the Dry Tortugas. This is the first station at which a nutrient stimulation of prophage
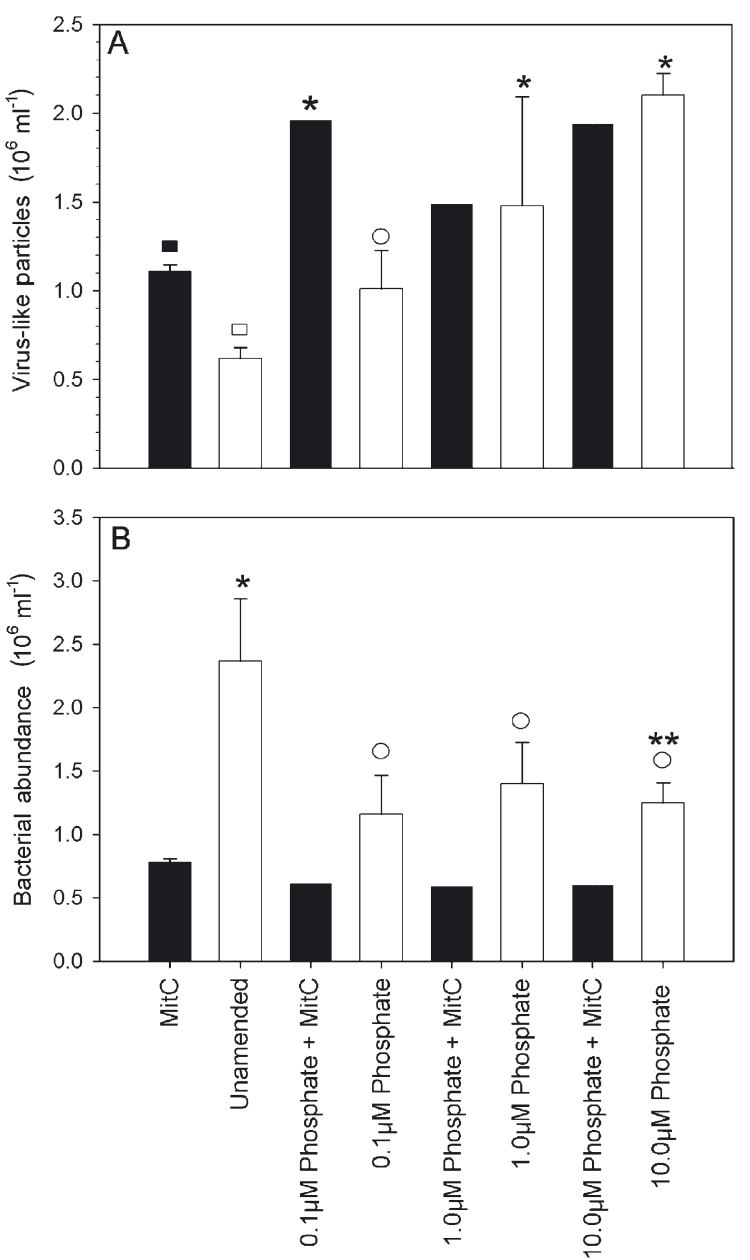

Fig. 5. (A) Viral and (B) bacterial abundance at Stn 10 following $24 \mathrm{~h}$ incubation with a gradient of $\mathrm{PO}_{4}{ }^{3-}$ concentration. Viral and bacterial abundances at $t=0$ were $2.88 \times 10^{6} \mathrm{ml}^{-1}$ and $4.81 \times 10^{5} \mathrm{ml}^{-1}$ respectively. *: statistically significant increase in viruses or bacteria $(95 \% \mathrm{CI})$ compared to nonnutrient amended control; **: statistically significant increase in bacteria (95\% CI) compared to mitomycin C-treated sample. O: nutrient-treated controls. Shading and error bars as for Fig. 2 induction occurred ( $0.1 \mu \mathrm{M} \mathrm{PO}_{4}{ }^{3-}$-treated sample). The addition of $0.1 \mu \mathrm{M} \mathrm{PO}_{4}{ }^{3-}$ to the mitomycin C-treated sample resulted in a statistically significant increase in phage production compared to both the sample that was treated with $0.1 \mu \mathrm{M} \mathrm{PO}_{4}{ }^{3-}$ alone as well as the sample treated with mitomycin $\mathrm{C}$ alone. This indicates that the addition of the nutrients to the mitomycin C-treated sample stimulated prophage induction. Statistically significant increases in phage production were also observed in the samples treated with 1.0 and $10.0 \mu \mathrm{M} \mathrm{PO}_{4}{ }^{3-}$ alone versus controls $(\mathrm{p}<0.001)$. The same pattern of viral increase was not detected when these specific concentrations of phosphate were added to the respective mitomycin C-treated samples, indicating that lytic production of phage was responsible for the detected increase in virus-like particles.

The addition of phosphate to water samples did not appear to cause an increase in bacterial abundance at this station compared to the unamended control (Fig. 5B). Bacterial abundance was statistically higher in the untreated water sample than in samples treated with the gradient of phosphate concentration ( $p<0.001)$. A statistically significant increase in bacterial abundance was also observed in the sample amended with $10.0 \mu \mathrm{M}$ $\mathrm{PO}_{4}{ }^{3-}$ alone compared to the sample treated with $10.0 \mu \mathrm{M} \mathrm{PO}_{4}{ }^{3-}$ and mitomycin $\mathrm{C}(\mathrm{p}=0.043)$.

\section{DISCUSSION}

In this study, we tested the hypothesis that prophage induction was nutrient-limited, by treating Gulf of Mexico water samples with a combination of nutrients and mitomycin $\mathrm{C}$ or with the nutrients alone as controls. Statistically significant increases in virus-like particles did occur on many occasions in nutrienttreated water samples regardless of whether mitomycin $\mathrm{C}$ was added or not. These results indicate that lytic, rather than lysogenic, bacteriophage production was stimulated by the addition of certain inorganic and organic nutrients.

A temperate bacteriophage must make a 'lysogenic decision' upon infection of a host cell, meaning the phage must choose whether to follow either the lytic or lysogenic pathway of infection. It is not currently understood what environmental factors influence the lysogenic decision in the marine environment. The molecular control of lysogeny has been well studied in the coliphage $\lambda$ (Ptashne 1992, Weaver 1999). In this system, cellular protease (FtsH) levels determine if a lytic or lysogenic interaction will be established between the virus and its host cell (Kihara et al. 2001). Cells grown in a rich medium have high levels of $\mathrm{FtsH}$, therefore favoring lytic phage production under nutrient-rich conditions. Our observations of a stimula- 
tion of lytic phage production in response to nutrient stimulation of host-cell growth supports the paradigm that nutrient-rich conditions favor lytic interactions with host cells, while nutrient-poor conditions may favor lysogenic interactions.

The availability of nutrients in the marine environment often dictates host-cell abundance, and may also be one of the environmental factors that influences lysogeny. Levin \& Lenski (1983) suggested that the concentration of nutrients might influence the lysogenic decision by modulating the metabolic activity of the host cell. Several studies have indicated that inorganic nutrient concentrations can modulate heterotrophic bacterial growth. Wheeler \& Kirchman (1986) demonstrated that heterotrophic bacterial growth rates were significantly higher following the addition of a mixture of inorganic (ammonium) and organic (glucose) nutrients to Gulf Stream water samples compared to organic nutrients alone (amino acids). Similarly, in another study, the addition of inorganic nitrogen to seawater off Scripps pier (San Diego, California) increased bacterial biomass (Horrigan et al. 1988). High nutrient concentrations ( $C, N$ and $P$ ) should support high host-cell abundance, which in turn favors lytic production of viruses. Alternatively, low nutrient concentrations should result in depleted host-cell populations, which should favor the establishment of lysogenic interactions with host cells. Theoretically, the addition of nutrients to water samples containing lysogenic populations of bacteria would stimulate prophage induction by altering the metabolic status of host-cell populations. In this study, the addition of both inorganic and organic nutrients appeared to simply stimulate the growth of bacterial populations, which thereby resulted in significant lytic production of viruses in these water samples.

Neither bacterial production nor mortality by grazing was measured in this study. We feel strongly that increases in bacterial abundance in the presence of nutrients compared to treatments lacking amendments was the result of bacterial growth, and actually represents a net bacterial growth. It has been argued that any increase in bacterial production would be rapidly eliminated by an increase in bacterial grazing (bacterivory). However, we would not expect the protistan population to increase or respond so rapidly (all incubations were $\leq 24 \mathrm{~h}$ ). For example, viral lysis has been shown to be tightly coupled to bacterial production, as indicated by relatively constant viral to bacterial ratios (VBRs; Choi et al. 2003). Grazing studies indicate that grazing rates can be highly variable compared to viral mortalities (Choi et al. 2003). Under non-steady-state conditions (i.e. nutrient amendment) bacterial mortality caused by viruses is generally greater than that caused by bacterivory (Guixa-Boixereu et al. 1999).
When nutrient pulses were observed from riverine input into the Bay of Biscay, there was a lag phase between peak abundance of bacteria and nonpigmented flagellates (Iriarte et al. 2003). This lag phase enabled bacteria to exploit substrate availability without grazing control for several days. Šimek et al. (2003) transplanted microbial populations from a lownutrient environment to a high-P environment and observed increased bacterial production and bacterivory compared to populations maintained under the low-nutrient conditions. There was an increase in bacterial and heterotrophic nanoflagellates and bacterivory in response to the $\mathrm{P}$ increase, yet this resulted in increased growth rates of all bacterial phylogenetic groups present. Only in the resource-limited control environment did bacterivory induce significant changes in bacterial community composition. Thus, in the present study, when increases in phage abundance co-occurred with increases in bacterial abundance in nutrient-amended samples, we believe that this was simply the result of nutrient stimulation of heterotrophic bacterial growth. We feel the tight coupling between viral lysis and bacterial growth caused the increase in viruses observed. Additionally, if the increases in viral abundance were due to the induction of prophage, we would have expected there to be a significant increase in the VBR. Conversely, VBRs did not vary significantly from $t_{0}$ to $t_{24}$, or between nutrient versus non-nutrient amended samples (data not shown). The relatively constant VBRs also indicate that the observed increases in viral abundance in the nutrient-amended samples were a reflection of bacterial growth.

Several studies have been conducted on natural marine water samples, whereby the concentration of phosphorus has been altered in order to determine the outcome on virus-host interactions, with conflicting results. Some studies have indicated that the addition of phosphorus to water samples enables prophage induction by lysogenic bacterial populations, thereby causing significant decreases in bacterial abundances (Tuomi et al. 1995), while one study indicated that the addition of phosphorus to natural Gulf of Mexico water samples stimulated bacterial growth (Stewart \& Levin 1984). We observed statistically significant increases in viral abundance at Stns 3, 8, and 10 in response to $\mathrm{PO}_{4}{ }^{3-}$ addition, often concurrent with an increase in bacterial abundance in the same samples. Ambient phosphate concentrations at Stn 3 and 8 were very similar $\left(\mathrm{PO}_{4}{ }^{3-}\right.$ concentration at $\mathrm{Stn} 8$ was slightly higher), and both were relatively low in comparison to a coastal environment such as Tampa Bay, Florida (Williamson et al. 2002). Increases in bacterial abundance at Stns 3 and 8 were most likely in response to the addition of a limiting nutrient essential for growth. 
A range of $\mathrm{PO}_{4}{ }^{3-}$ concentrations was added to water samples at Stn 10 in order to determine which concentration would be the most efficient at enabling prophage induction. In most cases, the addition of any $\mathrm{PO}_{4}{ }^{3-}$ to the system, regardless of concentration, resulted in an increase in viruses in comparison to samples that received no phosphate. Although it appears that nutrient stimulation of prophage induction occurred in the sample treated with both mitomycin $\mathrm{C}$ and $0.1 \mu \mathrm{M} \mathrm{PO}_{4}{ }^{3-}$, it is most likely that lytic production was responsible for the increases in phage observed in the 1.0 and $10.0 \mu \mathrm{MPO}_{4}{ }^{3-}$-treated samples. Although the higher concentrations of phosphate (1.0 and $10.0 \mu \mathrm{M}$ ) may enable prophage induction, these concentrations appear to be more efficient at stimulating lytic phage production. Therefore, any nutrient stimulation of prophage induction that did occur in response to the higher concentrations would go undetected in the presence of phage produced by lytic processes. Similarly, the lower concentration of phosphate $(0.1 \mu \mathrm{M})$ appeared to be sufficient for stimulation of prophage induction, but was not enough to stimulate or support lytic production of phage. The lower concentration may have enabled the phosphate-limited phage DNA-synthesis required for prophage induction to occur, without stimulating host-cell growth.

The majority of nutrient studies have focused on the modulating effects of phosphorus concentration on virus-host interactions, although some have included nitrogen compounds as well (Bratbak et al. 1993, Wilson et al. 1996, Hewson et al. 2001). Although inorganic nitrogen compounds were added to water samples at 2 stations in the present study, only $\mathrm{NH}_{4}{ }^{+}$ additions resulted in statistically significant increases in viruses at Stn 8. Total inorganic nitrogen concentration at this station was much lower than at other stations $(\mathrm{N}: \mathrm{P}$ ratio $=0.668)$, suggesting that the addition of $\mathrm{NH}_{4}{ }^{+}$to water samples encouraged lytic production of viruses in bacteria that may have been $\mathrm{N}$ limited.

In addition to inorganic nutrients, the effects of organic nutrient addition to water samples on virushost interactions was also investigated at Stns 7 and 8. The addition of organic nutrients to water samples at the mesotrophic Stn 7 did not appear to stimulate viral production compared to controls (data not shown). In contrast, the addition of organic nutrients to water samples at the oligotrophic Stn 8 did result in statistically significant increases in viruses compared to samples that remained untreated. Under nutrient-limiting conditions, heterotrophic bacteria are known to increase their uptake affinity for specific substrates, especially for sugars and phosphate, by lowering substrate-specificity (in the case of sugar compounds) and the use of scavenging enzymes including phospholi- pases and organophosphatases (Harder et al. 1984, Poindexter 1987). Significant increases in viruses at Stn 8 occurred in response to amino acid (glutamate), monosaccharide (glucose), nucleoside (adenosine), nucleotide (AMP), and high-energy phosphate (ATP) addition. Similar to inorganic addition, it appears that the addition of these organic nutrients to the oligotrophic water samples stimulated the metabolic activity of the ambient bacterial population, thereby encouraging lytic production of viruses.

Although our results indicate that nutrient addition (inorganic and organic) to Gulf of Mexico water samples stimulates lytic but not lysogenic production of viruses, lysogenic populations of bacteria are likely to co-exist in the same environment. The concentration of nutrients in a particular environment is only 1 variable hypothesized to influence lysogenic interactions, so it is not surprising that the addition of various inorganic and organic nutrients in combination with mitomycin $\mathrm{C}$ did not cause the transition from lysogenic and lytic existence at the time of sampling. It may be that other environmental factors (that were not investigated) were influencing the transition from lysogenic to lytic infection. Additionally, prophage induction in general may not have been detectable during the $2 \mathrm{wk}$ the samples were taken. In support of this theory, a previous study on the seasonal occurrence of lysogeny in Tampa Bay, Florida, showed that prophage-induction events were detected much more frequently in the winter months (December to March) than during the summer months (Williamson et al. 2002).

While mitomycin $\mathrm{C}$ is very effective at inducing prophage, not all lysogenic bacteria are inducible by this mechanism. Chemical-inducing agents such as a polychlorobiphenyl mixture and Aroclor 1248 have previously been shown to be more efficient at inducing natural populations of lysogenic bacteria in the marine environment (Cochran et al. 1998). However, in order that results be strictly comparable to those of other studies on the induction of natural populations, mitomycin $\mathrm{C}$ still is the inducting agent of choice. In addition, lysogenic populations may have already undergone induction via natural mechanisms (such as exposure to UV radiation), and therefore would remain undetected.

Even though the results of our study appear to indicate that prophage induction in mesotrophic and oligotrophic areas of the Gulf of Mexico was not nutrient-limited at the time of sampling, an alternative interpretation of the data suggests that nutrient amendment of water samples may have stimulated prophage induction, but that the overall nutrientlimited status of the host cells prevented successful phage synthesis of nucleic acid or phage particle assembly. This scenario is unlikely, since host-cell 
abundance increased in response to nutrient addition; therefore, nutrient amendment of water samples appeared to cause a general increase in the growth rate of host cells, which in turn resulted in an increase in lytic phage production.

Acknowledgements. This research was supported by grants from the National Science Foundation and the Tampa Bay Parrotheads in Paradise Club.

\section{LITERATURE CITED}

Ackermann HW, MS Dubow (1987) Viruses of prokaryotes, Vol I. General properties of bacteriophages. CRC Press, Boca Raton, FL

Bratbak G, Egge JK, Heldal M (1993) Viral mortality of the marine alga Emiliania huxleyi (Haptophyceae) and termination of algal blooms. Mar Ecol Prog Ser 93:39-48

Chen F, Lu JR, Binder BJ, Liu YC, Hodson RE (2001) Application of digital image analysis and flow cytometry to enumerate marine viruses stained with SYBR Gold. Appl Environ Microbiol 67:539-545

Choi DH, Whang CY, Cho BC (2003) Comparison of virus and bacterivory induced bacterial mortality in the eutrophic Masan Bay, Korea. Aquat Microb Ecol 30:117-125

Cochran PK, Kellog CA, Paul JH (1998) Prophage induction of indigenous marine lysogenic bacteria by environmental pollutants. Mar Ecol Prog Ser 164:125-133

Fuhrman JA (1992) Bacterioplankton roles in cycling of organic matter: the microbial food web. In: Falkowski PG, Woodhead A (eds) Primary productivity and biogeochemical cycles in the sea. Plenum Press, New York, p 361-384

Grasshoff K, Kremling K, Ehrhardt M (1999) Methods of seawater analysis. Wiley-Verlag Chemie, Weinheim

Guixa-Boixereu, N, Lysnes, K, Pedros-Alio, C (1999) Viral lysis and bacterivory during a phytoplankton bloom in a coastal water mesocosm. Appl Environ Microbiol 65: $1949-1958$

Harder W, Dijkhuizen L, Veldkamp H (1984) Environmental regulation of microbial metabolism. In: Kelly DP, Carr NG (eds) The microbe 1984. Part II. Prokaryotes and eukaryotes. Society for General Microbiology, Symposium 36. Cambridge University Press, Cambridge, p 51-95

Hewson I, O'Neil JM, Fuhrman JA, Dennison WC (2001) Virus-like particle distribution and abundance in sediments and overlying waters along eutrophication gradient in two subtropical estuaries. Limnol Oceanogr 46: $1734-1746$

Horrigan SG, Hagstrom A, Koike I, Azam F (1988) Inorganic nitrogen utilization by assemblages of marine bacteria in sea water culture. Mar Ecol Prog Ser 50:147-150

Iriarte A, Madariaga I, Revilla M, Sarobe A (2003) Short-term

Editorial responsibility: Jed Fuhrman,

Los Angeles, California, USA variability in microbial food web dynamics in a shallow tidal estuary. Aquat Microb Ecol 31:145-161

Kihara A, Akiyama Y, Ito K (2001) Revisiting the lysogenization control of bacteriophage lambda: identification and characterization of a new host component, HflD. J Biol Chem 276:13695-13700

Levin BR, Lenski RE (1983) Coevolution in bacteria and their viruses and plasmids. In: Futuyma DJ, Slatkin M (eds) Coevolution. Sinauer, Sunderland, MA, p 99-127

Noble RT, Fuhrman JA (1998) Use of SYBR Green I for rapid epifluorescence counts of marine viruses and bacteria. Aquat Microb Ecol 14:113-118

Poindexter JS (1987) Bacterial responses to nutrient limitation. In: Fletcher M, Gray TRG, Jones JG (eds) Ecology of microbial communities. Symposia of the Society for General Microbiology. Cambridge University Press, Cambridge, p 283-317

Ptashne M (1992) A genetic switch. Cell Press, Blackwell Scientific, Cambridge, MA

Šimek K, Hornak $K$, Masin M, Christaki U, Nedoma J, Weinbauer MG, Dolan JR (2003) Comparing the effects of resource enrichment and grazing on a bacterioplankton community of a meso-eutrophic resevoir. Aquat Microb Ecol 31:123-135

Stewart FM, Levin BR (1984) The population biology of bacterial viruses: why be temperate? Theor Popul Biol 26: 93-117

Tuomi P, Fagerbakke KM, Bratbak G, Heldal M (1995) Nutritional enrichment of a microbial community: the effects on activity, elemental composition, community structure, and virus production. FEMS Microbiol Ecol 16:123-134

Weaver RF (1999) Molecular biology. WCB/McGraw-Hill, Boston

Weinbauer MG, Suttle CA (1996) Potential significance of lysogeny to bacteriophage production and bacterial mortality in coastal waters of the Gulf of Mexico. Appl Environ Microbiol 62:4374-4380

Wheeler PA, Kirchman DL (1986) Utilization of inorganic and organic nitrogen by bacteria in marine systems. Limnol Oceanogr 31:998-1009

Wilhelm SW, Suttle CA (1999) Viruses and nutrient cycles in the sea. BioScience 49:781-788

Williamson SJ, Houchin LA, McDaniel L, Paul JH (2002) Seasonal variation in lysogeny as depicted by prophage induction in Tampa Bay, Florida. Appl Environ Microbiol 68:4307-4314

Wilson WH, Mann NH (1997) Lysogenic and lytic production in marine microbial communities. Aquat Microb Ecol 13: 95-100

Wilson WH, Carr NG, Mann NH (1996) The effect of phosphate status on the kinetics of infection in the oceanic cyanobacterium Synechococcus sp. WH7803. J Phycol 32: 506-516

Wommack KE, Colwell RR (2000) Viroplankton: viruses in aquatic ecosystems. Microbiol Mol Biol Rev 64:69-114

Submitted: October 18, 2003; Accepted: February 2, 2004

Proofs received from author(s): June 21, 2004 